\title{
KADAR MANGIFERIN PADA LIMA KULTIVAR PUCUK DAUN MANGGA (Mangifera indica L.)
}

\section{MANGIFERIN LEVELS IN FIVE YOUNG LEAF CULTIVAR OF MANGO (Mangifera indica L.)}

\author{
Tri Cahyanto*, Afriansyah Fadillah, Rizal Maulana Hasby, Risda Arba Ulfa, Ida Kinasih \\ Jurusan Biologi, Fakultas Sains dan Teknologi, Universitas Islam Negeri Sunan Gunung Djati Bandung, \\ Jl. A.H. Nasution No. 105, Cibiru, Bandung 40614 \\ *Corresponding author: tri_cahyanto@uinsgd.ac.id
}

Naskah Diterima: 25 Februari 2020; Direvisi: 13 April 2020; Disetujui: 18 April 2020

\begin{abstract}
Abstrak
Pemanfaatan pucuk daun mangga (Mangifera indica L.) oleh masyarakat menjadi lalapan dan dipercaya berkhasiat sebagai obat tradisional. Hal ini merupakan suatu proses kearifan lokal berdasarkan pengalaman empiris orang-orang terdahulu yang kemudian dijadikan kajian studi ilmiah, yaitu etnobotani. Kajian studi etnobotani termasuk pemanfaatan pucuk daun mangga sebagai lalapan masih jarang dilakukan. Penelitian ini bertujuan untuk mengetahui senyawa bioaktif termasuk mangiferin yang terkandung dalam lima kultivar mangga. Sampel kultivar mangga yang digunakan dalam penelitian antara lain Manalagi, Arum manis, Cengkir, Gedong apel dan Golek. Metode penelitian yang digunakan yaitu skrining fitokimia dan pengukuran kadar senyawa mangiferin dengan HPLC. Hasil penelitian menunjukkan sampel positif mengandung senyawa bioaktif alkaloid, flavonoid, saponin dan tanin. Kadar senyawa mangiferin paling tinggi secara berurutan terdapat pada kultivar Arum manis (20,83\%), Manalagi (20,56\%), Gedong apel (18,54\%), Cengkir (15,10\%), dan Golek (5,05\%). Kultivar mangga Arum manis memiliki kadar mangiferin paling tinggi, untuk selanjutnya dapat dikaji pemanfaatannya sebagai obat herbal tradisional.
\end{abstract}

Kata kunci: Etnobotani; Kultivar mangga; Mangiferin

\begin{abstract}
Utilization young leaf of mango (Mangifera indica L.) by the community as lalapan and it is believed to be efficacious as traditional medicines. This process through of local wisdom based on empirical experience of conservative people used as a scientific study, namely ethnobotany. Ethnobotany studies include the use of mango leaf shoots as fresh vegetables are still rarely performed.This study aims to determine bioactive compounds including mangiferin contained in five cultivars of mango. Mango cultivar samples used in this study include Manalagi, Arum manis, Cengkir, Gedong apel and Golek. The research method used was phytochemical screening and measurement of mangiferin compounds by HPLC. The results showed a positive sample containing bioactive compounds, alkaloids, flavonoids, saponins and tannins. The highest levels of mangiferin compounds were found in Arum manis (20.83\%), Manalagi (20.56\%), Gedong apel (18.54\%), Cengkir (15.10\%) and Golek (5.05\%). Arum manis cultivars has highest value of mangiferin levels, which can be explored for their use as traditional herbal medicines.
\end{abstract}

Keywords: Ethnobotany; Mangiferin; Mango cultivar

Permalink/DOI: http://dx.doi.org/10.15408/kauniyah.v13i2.14810 


\section{PENDAHULUAN}

Indonesia sebagai salah satu negara dengan luas wilayah 7,81 juta $\mathrm{km}^{2}$, memiliki keanekaragaman tumbuhan yang tinggi baik dari kelompok herba, semak ataupun pohon (Badan Pembinaan Hukum Nasional, 2015). Variasi berbagai macam tumbuhan tersebut memiliki potensi berbeda-beda yang dapat dimanfaatkan oleh masyarakat baik sebagai bahan pangan, sandang, papan, dan obatobatan (Khotimah, 2016).

Kearifan lokal dapat bersumber dari pengalaman empiris orang terdahulu, seperti dikenalnya suatu tumbuhan dengan nama daerah berdasarkan asal tumbuhan tersebut ditemukan. Pengetahuan tentang potensi tumbuhan tertentu didasarkan pada pengalaman orang terdahulu (Rahayu, 2011). Hal-hal tersebut secara tidak langsung menjadi sebuah pengetahuan yang berguna bagi orang banyak. Para ahli botani menghimpun pengetahuan masyarakat tersebut menjadi sebuah kajian keilmuan bernama etnobotani. Etnobotani yaitu ilmu tentang hubungan pengetahuan masyarakat (kearifan lokal) dengan ilmu botani, sehingga ditemukan sebuah informasi baru yang selanjutnya dapat digunakan masyarakat Indonesia dan seluruh dunia. Namun, etnobotani di Indonesia sendiri masih jarang dikaji dan diperdalam. Potensi tumbuhan tertentu sebagai lalapan di luar negeri dikenal dengan istilah sidedish (Prommajak, Kim, Pan, \& Kim, 2014). Secara etimologi lalapan berasal dari kata lalap, memiliki arti daun-daun muda. Lalapan mentimun, petai mentah yang dimakan bersama-sama dengan sambal dan nasi; ulam (Permatasari, Cahyanto, Adawiyah, \& Ulfa, 2018).

Salah satu jenis tumbuhan lalapan yang masih banyak dikonsumsi adalah pucuk daun mangga (Kadarsah \& Susilawati, 2018). Hal ini didasarkan pada banyaknya kultivar mangga yang tumbuh di berbagai wilayah di Indonesia. Di wilayah Subang Jawa Barat, diketahui memiliki keanekaragaman tumbuhan mangga yang cukup tinggi yaitu sekitar 21 kultivar (Cahyanto, Sopian, Efendi, \& Kinasih, 2017).

Secara tradisional pucuk daun mangga selain digunakan sebagai teman nasi oleh masyarakat, juga banyak digunakan sebagai obat diabetes karena mengandung senyawa bioaktif yang tinggi yakni mangiferin (Khandare, 2016). Takeda et al. (2016) menyatakan bahwa mangiferin merupakan senyawa flavonoid, polifenol tipe glikosil xanton yang telah diuji secara farmakologi. Mangiferin berguna sebagai antioksidan, antiinflamasi, dan perlindungan jaringan syaraf. Selain itu Shoji et al. (2011) menyatakan bahwa mangiferin berpotensi menjadi antikanker secara in vitro seluler pada acute myeloid leukemia (AML). Senyawa ini berpotensi sebagai analgesik, antidiabetik, antisklerotik, antimikroba, perlindungan hepar, antialergi, dan proteksi radiasi UV (Morales et al., 2017). Cahyanto et al. (2017) melaporkan kultivar Manalagi, Arum manis, Cengkir, Gedong apel dan Golek menjadi kultivar yang banyak ditemukan dan dibudidayakan oleh masyarakat khususnya Jawa Barat. Kultivar ini menjadi komoditas pangan terbesar di daerah penghasil mangga, Subang dan Indramayu. Pada penelitian ini dipilih kelima kultivar tersebut untuk diuji kadar senyawa mangiferin.

Kadar senyawa mangiferin pada pucuk daun kelima kultivar mangga diuji menggunakan metode skrining fitokimia, menggunakan pelarut metanol $(\mathrm{MeOH})$ dan etil asetat (EtoAc) serta high performance liquid chromatography (HPLC). Tujuan penelitian ini untuk mengetahui senyawa bioaktif termasuk mangiferin yang terkandung dalam lima kultivar manga sebagai data empiris dalam pemanfaatan lalapan pucuk daun mangga. Selanjutnya, informasi tersebut dapat digunakan untuk pengembangan secara farmakologis.

\section{MATERIAL DAN METODE}

Penelitian ini menggunakan sampel pucuk daun dari lima kultivar mangga yaitu Manalagi, Arum manis, Cengkir, Gedong apel dan Golek. Sampel diambil di sekitar wilayah Desa Manisi dan Cipadung, Kecamatan Cibiru, Bandung. Pucuk daun yang diambil berwarna kemerah-merahan, kecokelatan, kuning kecokelatan, kuning hijau kecokelatan (Prommajak et al., 2014) dari bagian ujung tangkai pohon, dengan bagian tingkatan pucuk paling ujung sampai bagian yang berbatasan dengan daun tua (Saifudin, 2014). Setiap sampel dibuat dalam ekstrak metanol dan etil asetat dari proses fraksi atau partisi cair-cair. 
Ekstrak metanol dan etil asetat dari setiap sampel selanjutnya dilakukan skrining fitokimia, yaitu alkaloid, flavonoid, saponin, dan tanin. Ekstrak metanol sampel tiap kultivar mangga diuji kadar mangiferin dengan menggunakan alat HPLC merk Agilent Technologies 1220 Infinity LC dengan detektor UV-Vis. Kolom HPLC yang digunakan jenis ODS merk Zorbax dengan kolom C-18 (4,6 x $250 \mathrm{~mm}, 5 \mu \mathrm{m})$. Standar mangiferin dibeli dari Sigma Aldrich (St. Louis, MO, U.S.A.). Panjang gelombang UV yang digunakan $\lambda=254 \mathrm{~nm}$. Fase gerak yang digunakan pada HPLC yaitu metanol:2\% asam asetat glasial dengan perbandingan 60:40 v/v. Laju alir yang digunakan $1 \mathrm{~mL} / \mathrm{min}$.

\section{Ekstraksi Sampel}

Sampel pucuk daun dari lima kultivar mangga yang digunakan, dikeringanginkan sehingga mudah dibuat menjadi serbuk. Sebanyak $20 \mathrm{~g}$ sampel setiap kultivar diekstraksi menggunakan metode maserasi dengan pelarut metanol selama 72 jam. Pemisahan ekstrak dengan pelarut menggunakan rotary evaporator. Ekstrak pekat atau maserat metanol ditimbang dan dihitung rendemennya. Maserat tiap sampel seberat $1 \mathrm{~g}$ ditambahkan sedikit air dan metanol kemudian dipartisi dengan larutan etil asetat, bagian yang terpisah pada pelarut etil asetat diambil.

\section{Skrining Fitokimia \\ Skrining Alkaloid}

Sebanyak $1 \mathrm{~mL}$ sampel hasil ekstrak metanol dan hasil partisi etil asetat ditambahkan kloroform $1 \mathrm{~mL}$ dan amoniak 1 $\mathrm{mL}$, kemudian diaduk dan disaring. Filtrat kemudian ditambahkan $\mathrm{H}_{2} \mathrm{SO}_{4}$ pekat 1-2 tetes untuk menetralkan dan diaduk kembali hingga terbentuk dua lapisan. Lapisan yang tidak berwarna dimasukkan ke dalam tiga tabung reaksi, masing-masing ditambahkan pereaksi Mayer, Wagner, dan Dragendorff sebanyak 23 tetes (Sari, 2013).

\section{Skrining Flavonoid}

Skrining fitokimia flavonoid menggunakan uji Wilstatter. Ekstrak metanol dan hasil partisi etil asetat sampel masingmasing ditambahkan potongan kecil magnesium $(\mathrm{Mg}), 2-4$ tetes hydrochloric acid
(HCl) $2 \mathrm{~N}$ pekat, etanol 2-4 tetes di atas tabel porselen, dan sedikit diaduk (Khotimah, 2016).

\section{Skrining Saponin}

Sebanyak 1-2 mL ekstrak metanol dan hasil partisi etil asetat sampel ditambahkan air panas, kemudian didinginkan dan dikocok kurang lebih 10 menit (Sari, 2013).

\section{Skrining Polifenol (Tanin)}

Ekstrak metanol dan hasil partisi etil asetat sampel sebanyak 1-2 mL dipanaskan di penangas air kemudian disaring. Filtrat ditambahkan larutan $\mathrm{FeCl}_{3}$ (Khotimah, 2016).

\section{Uji Kadar Senyawa Mangiferin dengan HPLC}

Kadar senyawa mangiferin pada sampel pucuk daun mangga dari lima kultivar diukur menggunakan HPLC. Sebelum pengukuran pada sampel, dibuat kurva baku standar mangiferin dengan konsentrasi 1 ppm, 5 ppm, $10 \mathrm{ppm}, 20 \mathrm{ppm}$, dan $25 \mathrm{ppm}$, sehingga didapatkan persamaan regresi kurva baku. Persamaan regresi kurva tersebut digunakan untuk mengukur kadar mangiferin pada sampel. Sampel setiap kultivar dibuat konsentrasi 100 ppm dengan melarutkan 100 mg sampel. Sampel diinjeksikan ke dalam kolom HPLC sebanyak $20 \mu \mathrm{L}$. Hasil pengukuran sampel dengan HPLC dan nilai persamaan kurva tersebut dimasukkan dalam rumus untuk dihitung kadar mangiferinnya

$=\frac{\text { (Hasil perhitungan persamaan garis lurus pada sampel) }}{\text { Bobot Simplisia atau sampel awal }} \times 100 \%$

\section{HASIL}

\section{Rendemen Ekstrak Metanol}

Hasil persentase rendemen dari lima sampel ekstrak metanol secara berturut-turut mulai dari nilai tertinggi ialah Arum manis (25\%), Manalagi (24,87\%), Gedong apel (24,37\%), Golek (24\%), dan Cengkir $(22,16 \%)$ (Gambar 1).

\section{Skrining Fitokimia}

Hasil skrining fitokimia menunjukkan sampel ekstrak metanol positif mengandung senyawa alkaloid, flavonoid, saponin dan polifenol (tanin). Sementara, sampel pada fraksi etil asetat negatif untuk senyawa saponin, tetapi positif senyawa lainnya (Tabel 1 dan 2). 


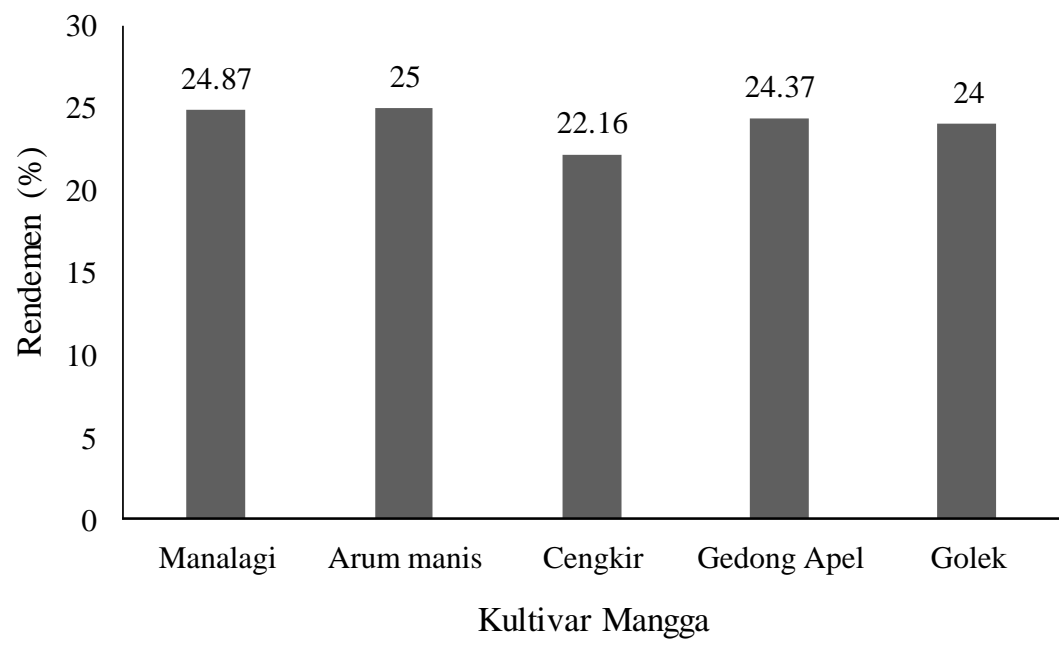

Gambar 1. Persentase rendemen ekstrak metanol lima kultivar mangga (Mangifera indica L.)

Tabel 1. Hasil skrining fitokimia alkaloid lima kultivar mangga (Mangifera indica L.)

\begin{tabular}{|c|c|c|c|c|c|c|c|c|c|c|}
\hline \multirow[b]{3}{*}{ Pereaksi } & \multicolumn{10}{|c|}{ Sampel } \\
\hline & \multicolumn{2}{|c|}{ Manalagi } & \multicolumn{2}{|c|}{ Arum manis } & \multicolumn{2}{|c|}{ Cengkir } & \multicolumn{2}{|c|}{ Gedong apel } & \multicolumn{2}{|c|}{ Golek } \\
\hline & Metanol & $\begin{array}{l}\text { Fraksi } \\
\text { etil asetat }\end{array}$ & Metanol & $\begin{array}{l}\text { Fraksi } \\
\text { etil asetat }\end{array}$ & Metanol & $\begin{array}{l}\text { Fraksi } \\
\text { etil asetat }\end{array}$ & Metanol & $\begin{array}{l}\text { Fraksi } \\
\text { etil asetat }\end{array}$ & Metanol & $\begin{array}{l}\text { Fraksi } \\
\text { Etil } \\
\text { asetat }\end{array}$ \\
\hline Wegner & + & + & + & + & + & + & + & + & + & + \\
\hline Mayer & + & + & + & + & + & + & + & + & + & + \\
\hline Dragendorff & + & + & + & + & + & + & + & + & + & + \\
\hline
\end{tabular}

Tabel 2. Hasil skrining fitokimia flavonoid, saponin, polifenol, dan tanin lima kultivar mangga (Mangifera indica L.)

\begin{tabular}{|c|c|c|c|c|c|c|c|c|c|c|}
\hline \multirow[b]{3}{*}{ Uji } & \multicolumn{10}{|c|}{ Sampel } \\
\hline & \multicolumn{2}{|c|}{ Manalagi } & \multicolumn{2}{|c|}{ Arum manis } & \multicolumn{2}{|c|}{ Cengkir } & \multicolumn{2}{|c|}{ Gedong apel } & \multicolumn{2}{|c|}{ Golek } \\
\hline & Metanol & $\begin{array}{l}\text { Fraksi } \\
\text { etil asetat }\end{array}$ & Metanol & $\begin{array}{l}\text { Fraksi } \\
\text { etil } \\
\text { asetat }\end{array}$ & Metanol & $\begin{array}{l}\text { Fraksi } \\
\text { etil } \\
\text { asetat }\end{array}$ & Metanol & $\begin{array}{l}\text { Fraksi } \\
\text { etil } \\
\text { asetat }\end{array}$ & Metanol & $\begin{array}{l}\text { Fraksi } \\
\text { etil } \\
\text { asetat }\end{array}$ \\
\hline Flavonoid & + & + & + & + & + & + & + & + & + & + \\
\hline Saponin & + & - & + & - & + & - & + & - & + & - \\
\hline Tanin & + & + & + & + & + & + & + & + & + & + \\
\hline
\end{tabular}

Keterangan:

$+=$ terdapat senyawa

- = tidak terdapat senyawa

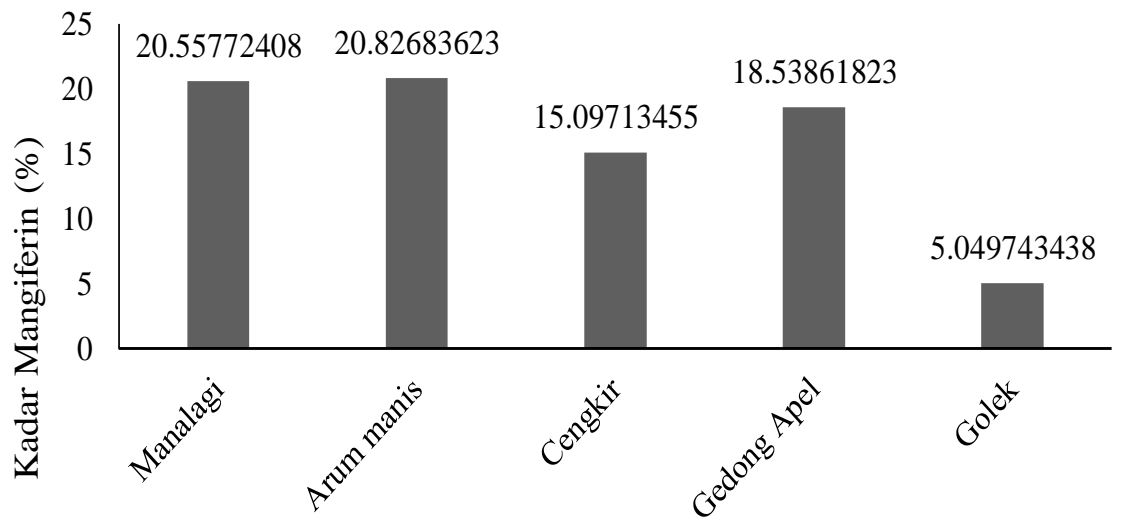

Kultivar Mangga

Gambar 2. Kadar mangiferin ekstrak metanol pucuk daun pada lima kultivar mangga (Mangifera indica L.). dengan menggunakan HPLC 


\section{Kadar Mangiferin Pucuk Daun Lima Kultivar Mangga (Mangiferin indica L.)}

Berdasarkan uji skrining fitokimia, ekstrak metanol menunjukkan hasil yang lebih positif dalam mengangkat senyawa yang terkadung di dalam sampel dibandingkan fraksi etil asetat. Sehingga pada tahap selanjutnya yaitu pengukuran kadar mangiferin yang digunakan adalah sampel dengan ekstrak metanol. Hasil pengukuran mangiferin pada lima kultivar mangga secara berurutan mulai dari nilai tertinggi yaitu kultivar Arum manis 20,83\%; Manalagi 20,56\%, Gedong apel 18,54\%; Cengkir 15,10\%; dan Golek 5,05\% (Gambar 2).

\section{PEMBAHASAN}

\section{Rendemen Ekstrak Metanol}

Berdasarkan hasil, kultivar Arum Manis memiliki persentase rendemen sebesar $25 \%$ (Gambar 1). Rendemen menunjukkan massa kandungan senyawa bioaktif dalam sampel. Tingginya nilai rendemen pada sampel memungkinkan senyawa bioaktif yang terdapat dalam sampel juga tinggi. Tingginya massa zat yang terangkat bergantung pada pelarut yang digunakan (Romansyah, 2011). Penelitian ini menggunakan pelarut metanol yang merupakan pelarut universal atau pelarut yang relatif mengangkat senyawa pada sampel lebih bervariasi, dengan syarat senyawa memiliki sifat kepolaran polar (Sari, 2013). Kemampuan metanol dalam menarik senyawa fitokimia dalam proses ektraksi juga karena sifat kepolaran polar yang dimiliki metanol (Harborne, 1987).

\section{Skrining Fitokimia}

Hasil positif pada uji alkaloid ditunjukkan dengan perubahan warna dan terbentuknya endapan pada sampel. Perubahan warna yang terjadi pada sampel dari merah kecokelatan merupakan akibat adanya ikatan kovalen koordinat antara ion $\mathrm{K}^{+}$dengan $\mathrm{N}$ pada alkaloid sampel (Khotimah, 2016). Sedangkan, hasil positif pada uji alkaloid dengan uji Mayer ditandai dengan karena adanya nitrogen pada sampel bereaksi dengan ion logam $\mathrm{K}^{+}$dari kalium tetraiodmerkurat (II) membentuk kalium-alkaloid kompleks sehingga terbentuk endapan dan perubahan warna pada sampel menjadi putih keruh. Hasil positif uji alkaloid dengan uji Dragendorff ditandai dengan perubahan warna sampel menjadi jingga kemerahan dan terbentuk endapan.

Hasil positif skrining flavonoid ditandai perubahan warna merah/jingga serta munculnya buih dan endapan. Menurut Tanaya, Retnowati, dan Suratmo (2015) serta Khotimah (2016), perubahan warna disebabkan hidrolisis yang terjadi akibat penambahan asam kuat $(\mathrm{HCl})$ sehingga flavonoid glikosida berubah menjadi aglikon flavonoid. Warna merah berasal dari garam flavilium yang biasanya muncul pada sampel yang mengandung flavonol, flavon, dan xanton. Sampel mengandung mangiferin yang merupakan golongan flavonoid tipe xanton (Jutiviboonsuk \& Sardsaengjun, 2010).

Hasil positif skrining saponin ditandai dengan terbentuknya busa di permukaan setelah sampel ditambahkan sedikit air panas dan dikocok. Busa tersebut timbul akibat senyawa pada sampel sebagian senyawa polar larut dalam air dan sebagian senyawa nonpolar menurunkan tegangan permukaan. Namun pada setiap sampel dari hasil fraksi etil asetat menunjukkan hasil negatif saponin. Hal ini kemungkinan karena senyawa saponin dalam sampel tidak terambil oleh etil asetat.

Skrining fitokimia tanin menunjukkan hasil positif pada setiap sampel. Hasil positif ditandai dengan perubahan warna menjadi hijau kehitam-hitaman. Pardede, Manjang, dan Efdi (2013) menyatakan hal tersebut terjadi akibat ikatan kovalen ion $\mathrm{Fe}^{3+}$ dengan atom $\mathrm{O}^{-}$ dari gugus fungsi $\mathrm{OH}^{-}$, kemudian senyawa tanin melepaskan atom $\mathrm{H}$ dan menghasilkan senyawa dengan diikuti perubahan warna.

\section{Kadar Mangiferin Pucuk Daun Lima Kultivar Mangga (Mangiferin indica L.)}

Berdasarkan hasil pengukuran, kultivar Arum manis berpotensi besar untuk dijadikan sebagai bahan hayati yang dimanfatkan dalam pengobatan karena memiliki mangiferin yang terukur lebih tinggi (Gambar 2)., Kemudian, hasil dari kultivar Golek memiliki persentase lebih rendah daripada kultivar Cengkir.Hasil ini berbanding terbalik dengan pengukuran rendemen. Hal tersebut diduga karena kultivar Golek memiliki warna pucuk daun yang relatif lebih hijau kekuningan dibanding kultivar lainnya, sehingga kandungan mangiferin pada 
pucuk daun rendah serta kandungan klorofil yang lebih banyak dibandingkan kultivar lainnya. Menurut Sumenda, Rampe, dan Mantiri (2011) daun yang memiliki warna relatif hijau kandungan mangiferin lebih rendah dibandingkan daun yang masih berwarna kemerahan.

Berdasarkan berbagai hasil penelitian diketahui bahwa senyawa mangiferin memiliki potensi untuk bahan farmakologi seperti antimikroba (Mustapha et al., 2014; Biswas, Sen, Roy, Maji, \& Maji, 2015), antiinflamasi (Saha, Sadhukhan, \& Sil, 2016), antidiabetes (Dineshkumar, Mitra, \& Manjunatha, 2010; Singh, Singh, \& Kochhar, 2012; Nayak \& De, 2013; Iliya et al., 2016), antijamur (Ningsih, Zusfahair, \& Mantari, 2017), antioksidan (Núñez-Sellés et al., 2002; Abdullah, Mohammed, Abdullah, \& Mirghani, 2015; Paulinus, Jayuska, Ardiningsih, \& Nofiani, 2015; Morales et al., 2017), antikanker secara in vitro (Morales et al., 2017), analgesik karena adanya gugus hidroksil bebas dan katekol (Dar et al., 2005; Prommajak et al., 2014). Mangiferin juga dapat menjadi antitumor serta peningkat daya tahan tubuh (Jutiviboonsuk \& Sardsaengjun, 2010). Mangiferin memenuhi syarat sebagai kandidat obat dari bahan hayati sebab berdasarkan aturan Lipinski, berat molekul mangiferin kurang dari 500 dengan nilai $\log \mathrm{P}=2,73$, ikatan donor dan aseptor hidrogennya $<5$ dan $<10$ serta bioavailabilitas pemberian obat secara per oral tinggi (Mirza, Chi, \& Chi, 2013). Hal tersebut didukung dengan tumbuhan mangga merupakan salah satu tumbuhan yang memiliki nilai ekonomis dan farmakologis, serta dalam beberapa penelitian, tumbuhan mangga disebutkan menjadi objek kajian etnobotani karena bagianbagian dari tumbuhan tersebut terdapat senyawa metabolit sekunder, yaitu mangiferin yang dapat berfungsi sebagai zat obat (Masibo \& He, 2008) dan dikonsumsi sebagai lalapan sebagai salah satu metode pengobatannya (Cahyanto, Supriyatna, Sholikha, Saepuloh, \& Rahmawati, 2018). Mangga kultivar Arum manis, Manalagi dan Gedong apel juga merupakan beberapa kultivar yang sering dikonsumsi serta berpotensi menjadi komoditas konsumsi nasional masyarakat khususnya di Indonesia, sehingga dalam penelitian ini dipilih kultivar-kultivar tersebut dan berasal dari daerah Jawa Barat (Cahyanto et al., 2017).

\section{SIMPULAN}

Pucuk daun dari lima kultivar mangga positif mengandung senyawa bioaktif diantaranya alkaloid, flavonoid, saponin dan tanin. Sementara, kadar senyawa mangiferin pada lima kultivar mangga berkisar antara 5,05-20,83\% dengan persentase paling tinggi pada kultivar mangga Arum manis. Dengan demikian, kultivar tersebut berpotensi paling besar untuk dijadikan sebagai bahan obat herbal tradisional.

\section{REFERENSI}

Abdullah, A.-S. H., Mohammed, A. S., Abdullah, R., \& Mirghani, M. E. S. (2015). Identification and quantification of phenolic compounds in Mangifera indica waterlily kernel and their free radical scavenging activity. Journal of Advanced Agricultural Technologies, 2(1), 1-7. doi.org/10.12720/joaat.2.1.1-7.

Badan Pembinaan Hukum Nasional (BPHN). (2015). Indonesia merupakan negara kepulauan yang terbesar di dunia. (2019, January 13). Retrieved from https://bphn.go.id/news/2015102805455 371/Indonesia-Merupakan-NegaraKepulauan-Yang-Terbesar-di-Dunia/

Biswas, T., Sen, A., Roy, R., Maji, S., \& Maji, H. S. (2015). Isolation of mangiferin from flowering buds of Mangifera indica L. and its evaluation of in vitro antibacterial activity. Journal of Pharmaceutical Analysis, 4(3), 49-56. doi: 10.1016/j.saa.2005.09.009.

Cahyanto, T., Sopian, A., Efendi, M., \& Kinasih, I. (2017). Grouping of Mangifera indica L. cultivars of Subang West Java by leaves morphology and anatomy characteristics. Biosaintifika: Journal of Biology \& Biology Education, 9(1), 156-167. doi: 10.15294/biosaintifika.v9i1.8780.

Cahyanto, T., Supriyatna, A., Sholikha, M., Saepuloh, A., \& Rahmawati, D. (2018, March 7-8). Inventory of plants used as lalapan in Subang, West Java. Paper presented at the $9^{\text {th }}$ International Conference on Global Resource Conservation (ICGRC) adm AJI from 
Ritsumeikan University, AIP Conference Proceedings 2019, Malang, Jawa Timur, Indonesia. Retrieved from https://aip.scitation.org/doi/pdf/10.1063/ 1.5061843

Dar, A., Faizi, S., Naqvi, S., Roome, T., Zikrur-Rehman, S., Ali, M., ... Moin, S. T. (2005). Analgesic and antioxidant activity of mangiferin and its derivatives: The structure activity relationship. Biological \& Pharmaceutical Bulletin, 28(4), 596-600. doi: 10.1248/bpb.28.596.

Dineshkumar, B., Mitra, A., \& Manjunatha, M. (2010). Studies on the anti-diabetic and hypolipidemic potentials of mangiferin (xanthone glucoside) in streptozotocininduced type 1 and type 2 diabetic model rats. International Journal of Advances in Pharmaceutical Sciences, 1(1), 75-85. doi:

10.5138/ijaps.2010.0976.1055.01009.

Harborne, J. B. (1987). Metode fitokimia: Penuntun cara modern menganalisis tumbuhan (2nd edition). Bandung: ITB Bandung.

Iliya, I. A., Mohammed, B., Akuyam, S. A., Yaro, J. D., Bauchi, Z. M., Tanko, M., ... Aghemunu, I. L. (2016). Immunohistochemical evaluation of the antidiabetic potentials of s-allyl-cysteine (garlic) and mangiferin (mango) in type 2 diabetic rat models. Sub-Saharan African Journal of Medicine, 3(1), 25-31. doi: 10.4103/2384-5147.176305.

Jutiviboonsuk, A., \& Sardsaengjun, C. (2010). Mangiferin in leaves of three thai mango (Mangifera indica L.) varieties. Isan Journal Pharmacy Sciences, 6(3), 122129.

Kadarsah, A., \& Susilawati, I. O. (2018). Kajian perbandingan luas pekarangan dan kearifan lokal jenis tanaman obat di pesisir pantai Kabupaten Tanah Laut. Jurnal Biodjati, 3(1), 36-46.

Khandare, M. S. (2016). Mango (Mangifera indica Linn) a medicinal and holy plant. Journal of Medicinal Plants Studies, 4(4), 44-46.

Khotimah, K. (2016). Skrining fitokimia dan identifikasi metabolit sekunder senyawa karpain pada ekstrak metanol daun Carica pubescens Lenne \& K. Koch dengan lc/ms (liquid chromatographtandem mass spectrometry) (Skripsi sarjana). Jurusan Biologi, Fakultas Sains dan Teknologi, UIN Maulana Malik Ibrahim, Malang, Indonesia.

Masibo, M., \& He, Q. (2008). Major mango polyphenols and their potential human health. Comprehensive Reviews in Food Science and Food Safety, 7(4), 309-319.

Mirza, R. H., Chi, N., \& Chi, Y. (2013). Therapeutic potential of the natural product mangiferin in metabolic syndrome. Journal of Nutritional Therapeutics, 2(2), 74-79.

Morales, M., Zapata, S., Jaimes, T. R., Rosales, S., Alzate, A. F., Maldonado, M. E., ... Rojano, B. A. (2017). Mangiferin content, carotenoids, tannins and oxygen radical absorbance capacity (orac) values of six mango (Mangifera indica) cultivars from the Colombian Caribbean. Journal of Medicinal Plants Research, 11(7), 144-152. doi: 10.5897/JMPR2017.6335.

Mustapha, A. A., Enemali, M. O., Olose, M., Owuna, G., Ogaji, J. O., \& Idris, M. M. (2014). Phytoconstituents and antibacterial efficacy of mango (Mangifera indica) leave extracts. Journal of Medicinal Plants Studies, 2(5), 19-23.

Nayak, A., \& De, S. (2013). Anti diabetic potential medicinal plants. BioMedRx Journal, 1(1), 32-46.

Ningsih, D. R., Zusfahair., \& Mantari, D. (2017). Ekstrak daun mangga (Mangifera indica L.) sebagai antijamur terhadap jamur Candida albicans dan identifikasi golongan senyawanya. Jurnal Kimia Riset, 2(1), 61-68.

Núñez-Sellés, A. J., Vélez-Castro, H. T., Agüero-Agüero, J., González-González, J., Naddeo, F., De Simone, F., \& Rastrelli, L. (2002). Isolation and quantitative analysis of phenolic antioxidants, free sugars and polyols from mango (Mangifera indica L.) stem bark aqueous decoction used in Cuba as a nutritional supplement. Journal of Agricultural and Food Chemistry, 50(4), 762-766. doi: 10.1021/jf011064b. 
Pardede, A., Manjang, Y., \& Efdi, M. (2013). Skrining fitokimia ekstrak metanol dari kulit batang manggis (Garcinia cymosa). Media Sains, 6(2), 60-66.

Paulinus, Y. V. G., Jayuska, A., Ardiningsih, P., \& Nofiani, R. (2015). Aktivitas antioksidan dan kandungan total fenol fraksi etil asetat buah palasu (Mangifera caesia Jack). Jurnal Kimia Khatulistiwa, 4(1), 47-50.

Permatasari, S., Cahyanto, T., Adawiyah, A., \& Ulfa, R. A. (2018). Pucuk daun mangga (Mangifera indica L.) kultivar cengkir sebagai penurun kadar glukosa darah. Bioma: Jurnal Biologi Dan Pembelajaran Biologi, 3(2), 102-112. doi: 10.32528/bioma.v3i2.1609.

Prommajak, T., Kim, S. M., Pan, C., \& Kim, S. M. (2014). Identification of antioxidants in young mango leaves by lc-abts and lcms. Chiang Mai University Journal of Natural Sciences, 13(3), 317-330. doi: 10.12982/cmujns.2014.0038.

Rahayu, S. M. (2011). Pemanfaatan tumbuhan obat oleh masyarakat Kabupaten Subang, Jawa Barat: Studi kasus di Kecamatan Jalancagak, Kecamatan Dawuan dan Kecamatan Tambakdahan (Skripsi sarjana). Departemen Konservasi Sumberdaya Hutan dan Ekowisata, Fakultas Kehutanan, Institut Pertanian Bogor, Bogor, Indonesia.

Romansyah, Y. (2011). Kandungan senyawa bioaktif antioksidan karang lunak Sacophyton sp. alami dan transplantasi di perairan Pulau Pramuka, Kepulauan Seribu (Skripsi sarjana). Departemen Ilmu dan Teknologi Kelautan, Fakultas Perikanan dan Ilmu Kelautan, Institut Pertanian Bogor, Bogor, Indonesia.

Saha, S., Sadhukhan, P., \& Sil, P. C. (2016). Review article mangiferin: A xanthonoid with multipotent anti-inflammatory potential. Biofactors: International Union of Biochemistry and Molecular Biology, 42(5), 459-474. doi: 10.1002/biof.1292.
Saifudin, A. (2014). Senyawa malam metabolit sekunder. Yogyakarta: Deepublish.

Sari, R. P. (2013). Analisis daya antioksidan pada ekstrak daun binahong (Anredera cordifolia (Ten.) Steenis) dengan metode dpph (2,2-diphenyl-1-pikrilhidrazil) (Skripsi sarjana). Jurusan Kimia Fakultas Sains dan Teknologi, Universitas Islam Negeri Sunan Gunung Djati Bandung, Bandung, Indonesia.

Shoji, K., Tsubaki, M., Yamazoe, Y., Satou, T., Itoh, T., Kidera, Y., ... Nishida, S. (2011). Mangiferin induces apoptosis by suppressing $\mathrm{Bcl}-\mathrm{xL}$ and XIAP expressions and nuclear entry of NF- $\mathrm{BB}$ in HL-60 cells. Archives of Pharmacal Research, 34(3), 469-475. doi: 10.1007/s12272-011-0316-8.

Singh, U., Singh, S., \& Kochhar, A. (2012). Therapeutic potential of antidiabetic nutraceuticals. Phytopharmacology, 2(1), 144-169.

Sumenda, L., Rampe, H. L., \& Mantiri, F. R. (2011). Analisis kandungan klorofil daun mangga (Mangifera indica L.) pada tingkat perkembangan daun yang berbeda. Jurnal Bioslogos, 1(1), 20-24.

Takeda, T., Tsubaki, M., Kino, T., Yamagishi, M., Iida, M., Itoh, T., ... Nishida, S. (2016). Mangiferin induces apoptosis in multiple myeloma cell lines by suppressing the activation of nuclear factor kappa b-inducing kinase. Chemico-Biological Interactions, 251(1), 26-33. doi: 10.1016/j.cbi.2016.03.018.

Tanaya, V., Retnowati, R., \& Suratmo. (2015). Fraksi semi polar dari daun mangga kasturi (Mangifera casturi Koesterm). Kimia Student Journal, 1(1), 778-784. 